\title{
Lipids of sulfate-reducing bacteria and sulfur-oxidizing bacteria found in the Dongsheng uranium deposit
}

\author{
JIANG Lei $^{1,2}$, CAI ChunFang ${ }^{1 *}$, ZHANG YongDong ${ }^{3}$, MAO Sheng Yi $^{3}$, SUN YongGe $^{3,4}$, \\ LI KaiKai ${ }^{1}$, XIANG Lei ${ }^{1,2}$ \& ZHANG ChunMing ${ }^{5}$ \\ ${ }^{1}$ Key Laboratory of Petroleum Resources Research, Institute of Geology and Geophysics, Chinese Academy of Sciences, Beijing 100029, China; \\ ${ }^{2}$ Graduate University of Chinese Academy of Sciences, Beijing 100049, China; \\ ${ }^{3}$ State Key Laboratory of Organic Geochemistry, Guangzhou Institute of Geochemistry, Chinese Academy of Sciences, Guangzhou 510640, China; \\ ${ }^{4}$ Department of Earth Science, Zhejiang University, Hangzhou 310027, China; \\ ${ }^{5}$ Department of Geochemistry, Yangtze University, Jingzhou 434023, China
}

Received September 13, 2011; accepted December 16, 2011; published online February 7, 2012

\begin{abstract}
U-bearing sandstones from the Dongsheng deposit in Ordos Basin contain abundant $\mathrm{C}_{15}-\mathrm{C}_{18}$ fatty acids. The fatty acids may have been derived from modern and ancient organisms including organisms from the intervals of $U$ mineralization. A certain amount of i15:0, a15:0, a17:0 fatty acids coexist with small amounts of i17:1 $107 \mathrm{c}$ and 10me16:0, characteristic biomarkers of Desulfovibrio and Desulfobacter sp., respectively. This indicates the existence of sulfate-reducing bacteria (SRB) in the sandstones. The presence of sulfur-oxidizing bacteria (SOB), such as Beggiatoa and Thioploca, is indicated by significant amounts of 16:1 $\omega 7 \mathrm{c}$ and 18:1 $\omega 7 \mathrm{c}$ fatty acids. The existence of the SRB in the deposit, as inferred from the fatty acids, is consistent with results from fossilized microorganisms and isotopic compositions of ore-stage pyrite. This suggests that the environment may have been favorable for the SRB to grow since ore formation (9.8-22 Ma). The bacteria may have degraded hydrocarbons directly, or indirectly utilized hydrocarbons degraded by oxic microbes in the deposits. This process may have produced ${ }^{12} \mathrm{C}$-rich calcite and prominent baseline humps of unresolved complex mixtures (UCM), and 25-demethylated hopanes and tricyclic terpanes. The existence of sulfur-oxidizing bacteria and sulfate-reducing bacteria in the deposit may have resulted in bacterial sulfate reduction to sulfide, re-oxidization of the sulfide to sulfate and subsequent reduction of the sulfate to sulfide. This assertion is supported by ore-stage pyrite with $\delta^{34} \mathrm{~S}$ values as low as $-39.2 \%$, and the lightest sulfate (about $11 \%$ o) measured during the Phanerozoic, a difference of more than $46 \%$.
\end{abstract}

fatty acids, sulfate-reducing bacteria, sulfur-oxidizing bacteria, anaerobic oxidation of petroleum, Dongsheng uranium deposit, Ordos Basin

Citation: Jiang L, Cai C F, Zhang Y D, et al. Lipids of sulfate-reducing bacteria and sulfur-oxidizing bacteria found in the Dongsheng uranium deposit. Chin Sci Bull, 2012, 57: 1311-1319, doi: 10.1007/s11434-011-4955-4

Roll-type sandstone-type uranium deposits contribute $18 \%$ of the world's uranium resources. Low exploitation costs and shallow burial conditions make the Dongsheng uranium deposit the most important uranium deposit exploited in China. Uranium minerals in sandstone-hosted ore deposits are mostly uraninite and coffinite. Uranium minerals have generally been attributed to $\mathrm{U}(\mathrm{VI})$ reduction by biogenic sulfides and organic matter under low temperature condi-

*Corresponding author (email: cai_cf@mail.iggcas.ac.cn) tions [1-4], and U(VI) stem from uranium-rich rocks leached by ground water or atmospheric water. Many researchers have found that there is a spatial association between uranium deposits and petroleum [3,5-8]. For example, uranium deposits are found in South Texas, Erlian, Kailu, Songliao and Tarim basins with petroleum reservoirs in deep strata, but without carbonaceous materials. However, until now only Curiale et al. [9] and Cai et al. [10] have presented biomarkers and carbon isotope data to support the hydrocarbon involvement in the uranium mineralization 
process.

On the other hand, laboratory experiments have shown that sulfate-reducing bacteria (SRB) are capable of utilizing $\mathrm{U}(\mathrm{VI})$ as the preferred electron acceptor for respiration and reduction of $\mathrm{U}(\mathrm{VI})$ to $\mathrm{U}(\mathrm{IV})$ directly [12-14]. However, little direct evidence of biogenically precipitated $U$ minerals, and mainly of morphological nature, has been provided for uranium deposits $[5,15]$. Recently, robust mineralogical and geochemical evidence has been presented for the involvement of bacterial activity in the genesis of Dongsheng rollfront-type deposits of China $[10,11,16]$. The deposit has the latest stage of mineralization ages between 9.8-22 Ma. No evidence has been presented to indicate that the physical and chemical conditions have changed dramatically since then. Thus, it is possible that the microbial population in the deposit may not have greatly changed. The fossilized microorganisms found in the deposit [10] and the fatty acid methyl esters detected from the neighboring mudstone [17], suggest a favorable preservation environment for lipids of sulfate-reducing bacteria.

This study aimed to determine if sulfate-reducing bacteria and other microbes have existed in the Dongsheng deposit, and to further elucidate the mechanism of bacterial mineralization. This research included analyses of biomarkers from fatty acids and saturated hydrocarbon fractions.

\section{Geological setting}

Ordos Basin is one of the largest sedimentary basins in China. It covers an area of about $250000 \mathrm{~km}^{2}$, and stretches across Shanxi, Gansu, Ningxia and Inner Mongolia. The basin is surrounded by mountains, bordered to the east by the Lüliang and Zhongtiao Mountains, to the west by the Helan and Liupan Mountains, to the north by the Langshan, Yinshan and Daqing Mountains and to the south by Qinling.
The basin is rich in energy resources, such as coal, oil, natural gas and uranium.

Dongsheng roll-type uranium deposits lie in the eastern part of the Yimeng uplift in Ordos Basin (Figure 1(a)). U-bearing sandstones constitute Middle Jurassic Zhiluo Formation braided river facies of grey, grey-white and greygreen colored, middle- to coarse-grained sandstone with abundant pyrite aggregates, oil-gas inclusions and adsorbed hydrocarbons. There are three suits of hydrocarbon source rocks in the basin, including Ordovician marine carbonate, Permo-Carboniferous coal measures and dark mudstones of the lacustrine facies of the Upper Triassic Yanchang Formation. The Yanchang Formation is the main hydrocarbon source rock for the Mesozoic oil pools in the Shanbei slope unit of the basin. The Dongsheng deposit may have hydrocarbons derived from source rocks laid down in an environment similar to the Yanchang Formation in the Shanbei slope $[10,18,19]$, although these source rocks do not occur in the study area. Affected by the Mesozoic IndosinianYanshan and Cenozoic Himalayan movements, many faults have developed in the northern part of the basin, which may have acted as major pathways for upward migration of petroleum from deep strata. The host sandstone experienced maximum burial and heating during the end of the Early Cretaceous, and had palaeo-temperatures of $<70^{\circ} \mathrm{C}$, based on reconstruction of the burial and thermal history from well S1 (Figure 1(a)) [11].

\section{Samples and experimental design}

Five grey, grey-white and grey-green colored, U-bearing sandstone samples were collected from Zhaohuohao, Sunjialiang and Shashagetai within the Middle Jurassic Zhiluo Formation (Figure 2(b)) and analyzed for biomarkers of fatty acids and saturated hydrocarbons.

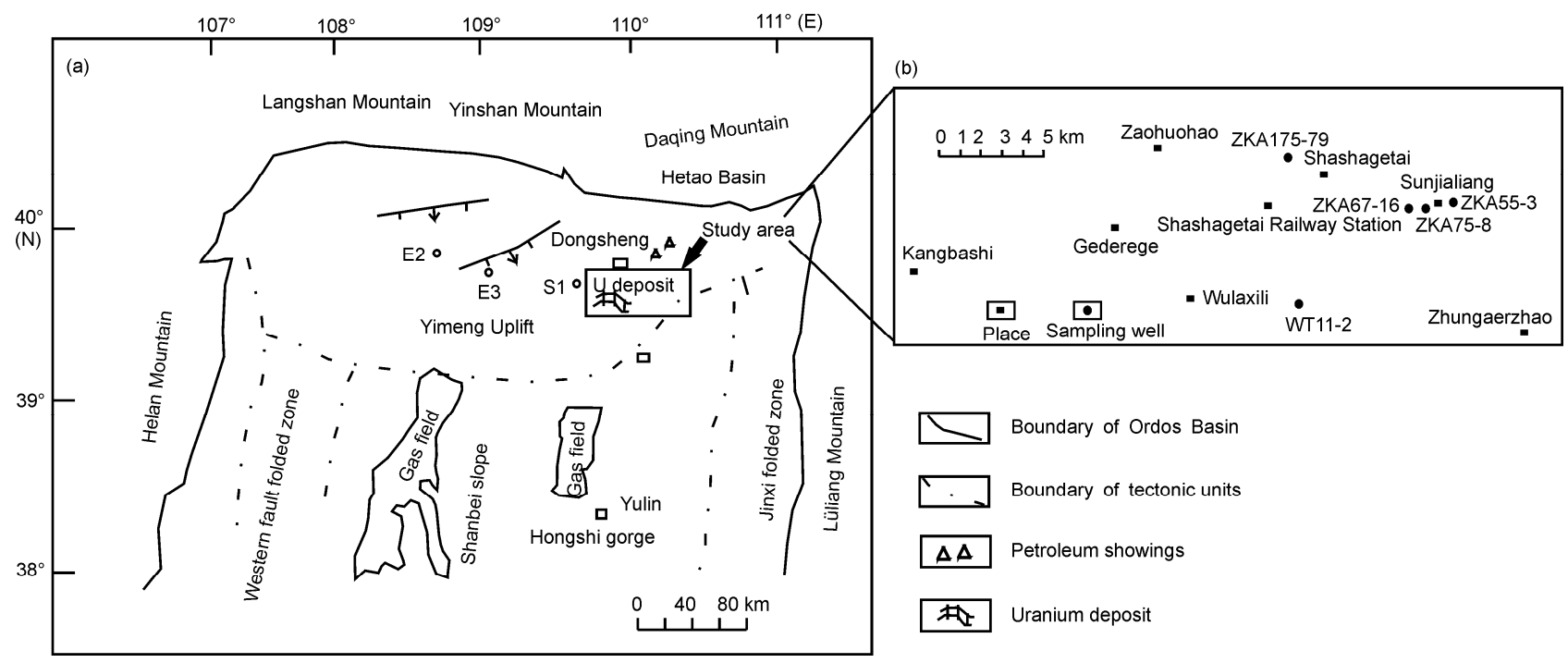

Figure 1 (a) The geology and location of the Dongsheng uranium deposit; (b) sampled wells. 


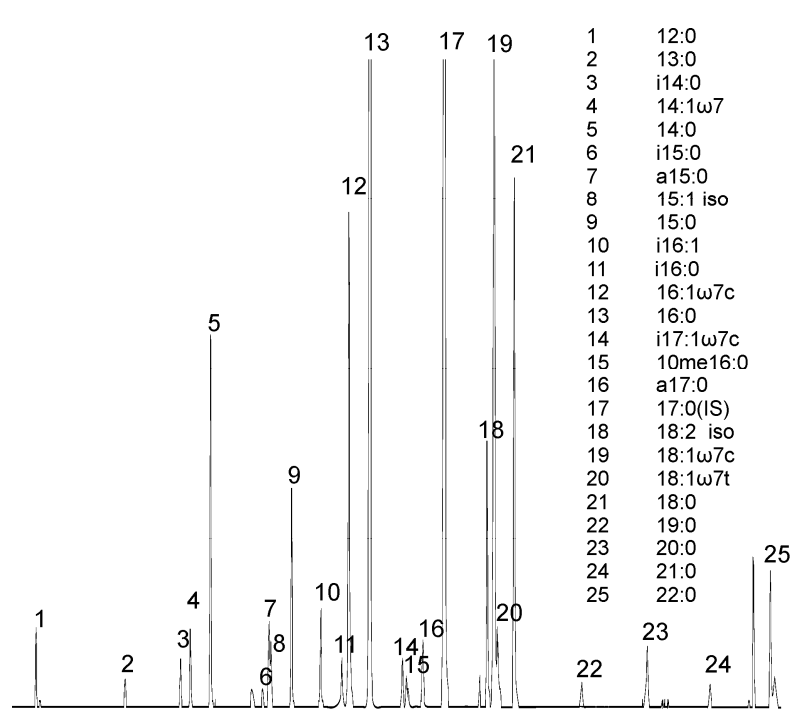

Figure 2 Capillary chromatograph of fatty acids (as methyl esters) extracted from Zhiluo Formation sandstones.

\subsection{Fatty acid extraction and GC-MS analyses}

A method similar to Duan et al. [20] was used to extract fatty acids. The samples used for total organic carbon (TOC) and fatty acids determination were ground to a $200 \mathrm{~mm}$ mesh size. About 70 to $100 \mathrm{~g}$ of powered sample were extracted with dichloromethane and methanol $(2: 1)$ for $72 \mathrm{~h}$ in a Soxhlet apparatus. Daturic acid was then added to the extractable organic matter, and saponified with a $\mathrm{KOH}-$ methanol solution. Then, neutral lipids were separated, acidified and filtrated, until only fatty acid compounds remained. Subsequently, a boron trifluoride-methanol solution was added to transform the fatty acids into fatty acid methyl esters (FAMEs) prior to GC-MS analysis.

FAMEs were analyzed by GC-MS using a Thermo Scientific DSQ II mass spectrometer coupled to a Thermo Scientific Trace gas chromatograph [21]. Chromatographic separation was achieved by using a $(60 \mathrm{~m} \times 0.32 \mathrm{~mm} \times 0.25$ $\mu \mathrm{m})$ capillary column. The oven temperature program started at $70^{\circ} \mathrm{C}(5 \mathrm{~min})$, and then changed from $80^{\circ} \mathrm{C}$ to $290^{\circ} \mathrm{C}$ at a rate of $3^{\circ} \mathrm{C} / \mathrm{min}$. This temperature was maintained for $20 \mathrm{~min}$. Helium was used as the carrier gas at a flow rate of $1.1 \mathrm{~mL} / \mathrm{min}$. The ion source temperature was $250^{\circ} \mathrm{C}$. The ion source was operated in the electron impact (EI) mode at $70 \mathrm{eV}$. Full scanning and the selected ion monitoring (SIM) mode were used simultaneously. The positions of double bonds in monounsaturated fatty acid methyl esters were determined by gas chromatographymass spectrometry of the dimethyl disulfide adducts [22].

\subsection{Saturated hydrocarbon extraction and GC-MS analysis}

The sandstone samples used for petroleum compounds analysis were crushed to $>200 \mathrm{~mm}$, and then extracted with dichloromethane for $72 \mathrm{~h}$ in a Soxhlet apparatus. Extracted organic matter was separated into saturated, aromatic and non-hydrocarbon fractions by a silica gel column, respectively. Saturated hydrocarbon analyses were performed with a Hewlett Packard 6890GC/5973MSD mass spectrometer. The gas chromatography (GC) was fitted with a HP-5MS capillary column $(30 \mathrm{~m} \times 0.25 \mathrm{~mm} \times 0.25 \mu \mathrm{m})$. Helium was used as the carrier gas $(1.0 \mathrm{~mL} / \mathrm{min})$. The temperature was increased from $50^{\circ} \mathrm{C}(1 \mathrm{~min})$ to $310^{\circ} \mathrm{C}$ at a rate of $3^{\circ} \mathrm{C} / \mathrm{min}$, and then held at $310^{\circ} \mathrm{C}$ for $18 \mathrm{~min}$. All analyses were carried out both in selected ion and full scan double modes. Fatty acids were identified by mass spectra, relative retention times and comparison with published data [20,23-27]. Fatty acid nomenclature is in the form of "A:B $\omega \mathrm{C}$ ", where "A" designates the total number of carbons, "B" designates the number of double bonds, and " $C$ " designates the distance of the closest unsaturation from the aliphatic end of the molecule. The suffixes "c" for cis and " $t$ " for trans refer to geometric isomers. The prefixes "i" "a" and "me" refer to iso and anteiso methyl branching and mid-chain methyl branching, respectively.

\section{Results}

\subsection{Fatty acids profiles}

From organic matter present as free, absorbed forms and fluid inclusions in the sandstone samples, 25 kinds of fatty acids were detected, with $\mathrm{C}_{12}-\mathrm{C}_{22}$ fatty acids dominating for all the samples. The fatty acids consisted mainly of monosaturated, branched saturated, and monounsaturated structures. The fatty acids had carbon numbers of mostly no more than $\mathrm{C}_{18}$, with a predominance of even carbon numbers. The high carbon number fatty acids and polyunsaturated fatty acids were minor components. Fatty acids with carbon numbers greater than $\mathrm{C}_{22}$ and cyclic fatty acids were below detection limits (Figures 2, 3; Table 1).

In all samples, 16:0 dominated the saturated fatty acids (Figure 4(a)). Fatty acids i15:0, a15:0 plus a17:0 are main branched saturated fatty acids (Figure 4(b)), while 16:1 and 18:1 isomers dominate the monounsaturated fatty acids

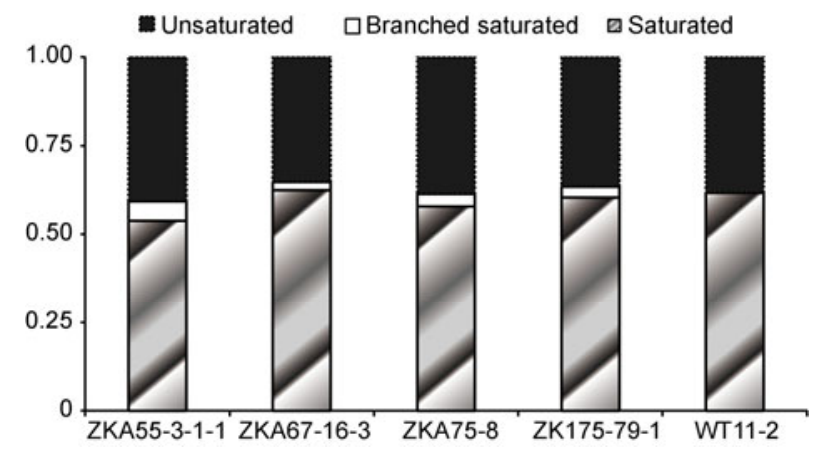

Figure 3 Distribution of saturated, branched saturated and unsaturated fatty acids. 
Table 1 The absolute content and relative mole percentage of the fatty acids in Zhiluo Formation sandstones ${ }^{\text {a) }}$

\begin{tabular}{|c|c|c|c|c|c|c|c|c|c|c|}
\hline & \multicolumn{2}{|c|}{ ZKA55-3-1-1 } & \multicolumn{2}{|c|}{ ZKA67-16-3 } & \multicolumn{2}{|c|}{ ZKA75-8 } & \multicolumn{2}{|c|}{ ZK175-79-1 } & \multicolumn{2}{|c|}{ WT11-2 } \\
\hline Depth (m) & \multicolumn{2}{|c|}{137.5} & \multicolumn{2}{|c|}{137.2} & \multicolumn{2}{|c|}{123.2} & \multicolumn{2}{|c|}{152.1} & \multicolumn{2}{|c|}{159.8} \\
\hline $\mathrm{U}(\mathrm{ppm})$ & \multicolumn{2}{|l|}{110} & \multicolumn{2}{|l|}{115} & \multicolumn{2}{|c|}{80} & \multicolumn{2}{|l|}{60} & \multicolumn{2}{|c|}{90} \\
\hline Extract $(\mathrm{g})$ & \multicolumn{2}{|c|}{95.37} & \multicolumn{2}{|c|}{78.99} & \multicolumn{2}{|c|}{97.10} & \multicolumn{2}{|c|}{68.51} & \multicolumn{2}{|c|}{69.50} \\
\hline Name & Con. (ng/g) & $\mathrm{mol} \%$ & Con. (ng/g) & mol\% & Con. (ng/g) & $\mathrm{mol} \%$ & Con. (ng/g) & $\mathrm{mol} \%$ & Con. (ng/g) & mol $\%$ \\
\hline 12:0 & 45 & 1.02 & 0 & 0.00 & 0 & 0.00 & 0 & 0.00 & 0 & 0.00 \\
\hline 13:0 & 15 & 0.35 & 0 & 0.00 & 4 & 0.23 & 4 & 0.16 & 0 & 0.00 \\
\hline i14:0 & 33 & 0.76 & 0 & 0.00 & 6 & 0.37 & 8 & 0.32 & 0 & 0.00 \\
\hline $14: 1 \omega 7 \mathrm{c}$ & 49 & 1.12 & 0 & 0.00 & 7 & 0.42 & 7 & 0.27 & 0 & 0.00 \\
\hline 14:0 & 254 & 5.80 & 68 & 3.25 & 57 & 3.31 & 71 & 2.74 & 15 & 3.60 \\
\hline i15:0 & 17 & 0.40 & 0 & 0.00 & 2 & 0.15 & 3 & 0.12 & 0 & 0.00 \\
\hline a15:0 & 48 & 1.10 & 13 & 0.61 & 10 & 0.56 & 15 & 0.57 & 0 & 0.00 \\
\hline $15: 1$ iso & 45 & 1.02 & 9 & 0.41 & 6 & 0.37 & 6 & 0.24 & 0 & 0.00 \\
\hline 15:0 & 149 & 3.40 & 37 & 1.76 & 29 & 1.71 & 32 & 1.23 & 6 & 1.59 \\
\hline $16: 1$ & 61 & 1.39 & 12 & 0.56 & 15 & 0.88 & 11 & 0.41 & 0 & 0.00 \\
\hline i16:0 & 13 & 0.30 & 0 & 0.00 & 0 & 0.00 & 0 & 0.00 & 0 & 0.00 \\
\hline a16:0 & 29 & 0.67 & 11 & 0.51 & 6 & 0.33 & 11 & 0.44 & 0 & 0.00 \\
\hline $16: 1 \omega 7 \mathrm{c}$ & 381 & 8.70 & 95 & 4.51 & 84 & 4.92 & 76 & 2.95 & 11 & 2.67 \\
\hline 16:0 & 1313 & 30.02 & 872 & 41.56 & 619 & 36.16 & 1017 & 39.47 & 178 & 43.94 \\
\hline $\mathrm{i} 17: 1 \omega 7 \mathrm{c}$ & 30 & 0.68 & 9 & 0.42 & 9 & 0.50 & 7 & 0.28 & 0 & 0.00 \\
\hline 10me16:0 & 14 & 0.33 & 4 & 0.18 & 4 & 0.21 & 4 & 0.16 & 0 & 0.00 \\
\hline a17:0 & 58 & 1.32 & 15 & 0.70 & 13 & 0.78 & 15 & 0.58 & 0 & 0.00 \\
\hline 17:0(IS) & 0 & & 0 & & 0 & & 0 & & 0 & \\
\hline $18: 2$ iso & 190 & 4.35 & 71 & 3.36 & 58 & 3.37 & 89 & 3.45 & 13 & 3.13 \\
\hline $18: 1 \omega 7 \mathrm{c}$ & 903 & 20.65 & 500 & 23.83 & 450 & 26.25 & 657 & 25.50 & 125 & 30.92 \\
\hline $18: 1 \omega 7 \mathrm{t}$ & 75 & 1.71 & 36 & 1.74 & 27 & 1.59 & 91 & 3.55 & 7 & 1.67 \\
\hline 18:0 & 370 & 8.47 & 234 & 11.14 & 180 & 10.52 & 289 & 11.23 & 51 & 12.49 \\
\hline 19:0 & 28 & 0.63 & 12 & 0.57 & 13 & 0.77 & 16 & 0.61 & 0 & 0.00 \\
\hline 20:0 & 50 & 1.14 & 22 & 1.06 & 25 & 1.43 & 29 & 1.13 & 0 & 0.00 \\
\hline 21:0 & 28 & 0.64 & 12 & 0.58 & 8 & 0.48 & 19 & 0.72 & 0 & 0.00 \\
\hline 22:0 & 101 & 2.31 & 51 & 2.43 & 55 & 3.23 & 77 & 3.00 & 0 & 0.00 \\
\hline $\mathrm{TL}$ & 4375 & & 2097 & & 1712 & & 2576 & & 405 & \\
\hline
\end{tabular}

a) Con.: content; TL: total fatty acids content.
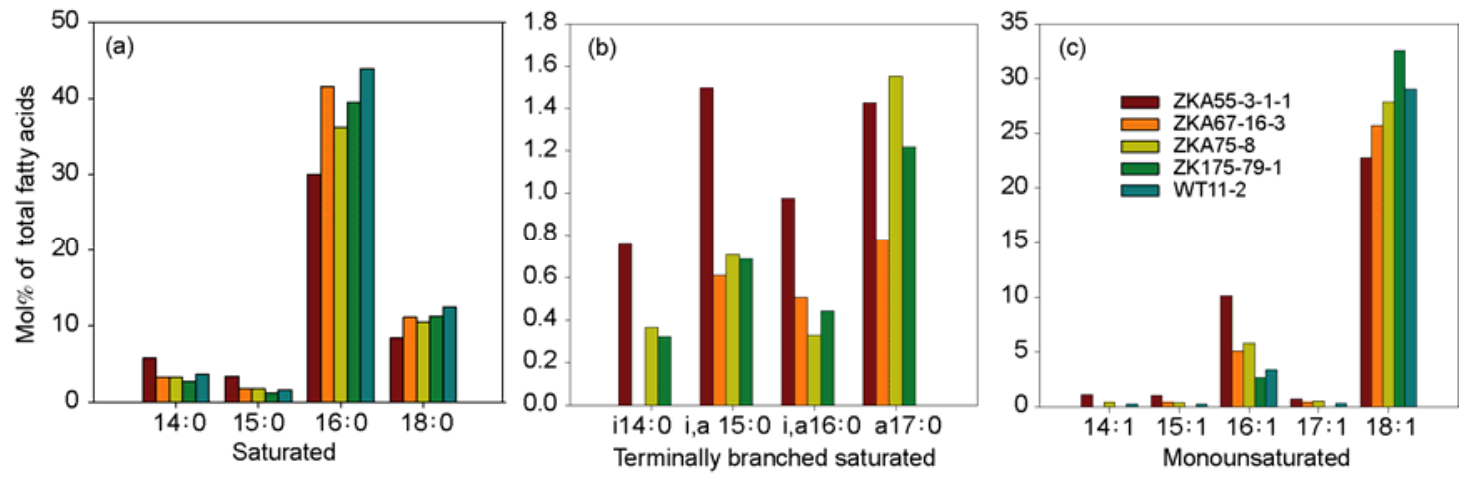

Figure 4 Relative abundance of individual fatty acids. Branched fatty acids included both iso (i) and anteiso (a) compounds. Monounsaturated fatty acids included all isomers.

(Figure 4(c)). Unsaturated fatty acids, such as 16:1 $1 \omega 7,18: 2$ isomers, 18:1 107 were detected in all samples. However, unsaturated fatty acids, such as 14:167, 15:1 isomers or i17:1 $107 \mathrm{c}$, also were detected in some samples.

The total fatty acids had concentrations from 405 to 4375 ng/g $(n=5)$. Total branched saturated fatty acids consisted mainly of i15:0, a15:0 and a17:0, with low concentrations of $0-150 \mathrm{ng} / \mathrm{g}(n=5)$. Monounsaturated fatty acids consisted mainly of $16: 1 \omega 7 \mathrm{c}$ and $18: 1 \omega 7 \mathrm{c}$, with concentrations from 140 to $1400 \mathrm{ng} / \mathrm{g}(n=5)$ (Table 1$)$. Significantly, fatty acids such as $117: 1 \omega 7 \mathrm{c}$ and $10 \mathrm{me} 16: 0$ were detected from the sandstones, with concentrations from 7 to $30 \mathrm{ng} / \mathrm{g}(n=5)$ and from 4 to $14 \mathrm{ng} / \mathrm{g}(n=5)$, respectively. 10me16:0 exhibited a molecular ion peak at $m / e 284$ and characteristic ion peaks 
at $m / e$ 129, 130, 171, 172, 173 and 199 (Figure 5), which is very similar to published data [28].

\subsection{Biomarkers of petroleum hydrocarbons}

Four GC-MS data $(m / z=85)$ analyzed in this study had $\mathrm{Pr} / \mathrm{nC}_{17}$ and $\mathrm{Ph} / \mathrm{nC}_{18}$ ratios from 0.52 to 0.9 and 0.50 to 0.94 (Table 2), respectively. These data show prominent humps of unresolved complex mixtures (UCM) (Figure 6(a)). The oils contained $\mathrm{C}_{26}-\mathrm{C}_{29} 17 \alpha, 21 \beta 25$-norhopanes and demethylated $\mathrm{C}_{28}-\mathrm{C}_{29}$ tricyclic terpanes (Figure 6(b),(c)). $\mathrm{C}_{29}$ $17 \alpha, 21 \beta 25$-norhopane (29DH) was relatively abundant, with the $29 \mathrm{DH} / 30 \mathrm{H}\left(30 \mathrm{H}=\mathrm{C}_{30} 17 \alpha, 21 \beta\right.$ hopane $)$ ratios ranging from 0.15 to 0.16 , and $29 \mathrm{DH} / 29 \mathrm{H}\left(29 \mathrm{H}=\mathrm{C}_{29} 17 \alpha\right.$, $21 \beta 30$-norhopane) from 0.30 to 0.33 (Table 2). The results are consistent with Cai et al. [10].

\section{Discussion}

\subsection{Origin of fatty acids}

Fatty acids in sediments may be derived from terrestrial higher plants, microorganisms, larger animals or synthesis by microbes. Since the sandstones and hydrocarbons of this study were all derived from non-marine environments [10], marine organisms can be ruled out as the sources of fatty acids in the deposit. Several lines of evidence indicate that the fatty acids detected were mainly derived from bacteria. First, long-chain $\left(>\mathrm{C}_{25}\right) n$-alkyl fatty acids typical of leaf waxes from terrestrial higher plants [29] were below detec- tion limits in all samples. Second, polyunsaturated fatty

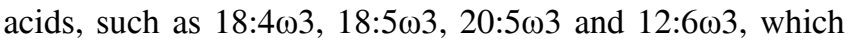
are enriched in planktonic organisms such as flagellates, diatoms, and dinoflagellates, were not detected. Third, it has been shown that i15:0, a15:0, i17:0 and a17:0 fatty acids can be synthesized by microbes [30]. Finally, bacteria have been shown to have fatty acids with carbon numbers mainly between $\mathrm{C}_{12}$ to $\mathrm{C}_{20}$, containing abundant branched saturated and monounsaturated fatty acids [20,22-27,31,32]. The fatty acids detected in this study contained branched saturated fatty acids (e.g. i15:0, a15:0, i17:0, a17:0) and monounsaturated fatty acids (e.g. 16:1 and 18:1 isomers) with carbon numbers ranging from $\mathrm{C}_{15}$ to $\mathrm{C}_{18}$. These features are similar to the distribution of bacterial fatty acids [20,22-27, 31,32]. Thus, the fatty acids detected in these deposits mainly were derived from bacteria.

\subsection{Identification of sulfate-reducing bacteria and sulfur-oxidizing bacteria}

Previous studies have shown that sulfate-reducing bacteria contain odd carbon number fatty acids, such as iso- and anteiso-fatty acids (i.e. i15:0, a15:0, i17:0, and a17:0) [23-27,33-36]. Fatty acid 10me16:0 was previously found only in actinomycetes [37] and Agrobacterium tumefaciens [38]. However, more recently, Dowling et al. [39] showed that the presence of 10me16:0 and cy 17:0 without high levels of 10me18:0 may have the potential to act as biomarkers for Desulfobacter sp. in marine sulfate-reducing environments. This suggestion has been accepted widely [26,33,39].

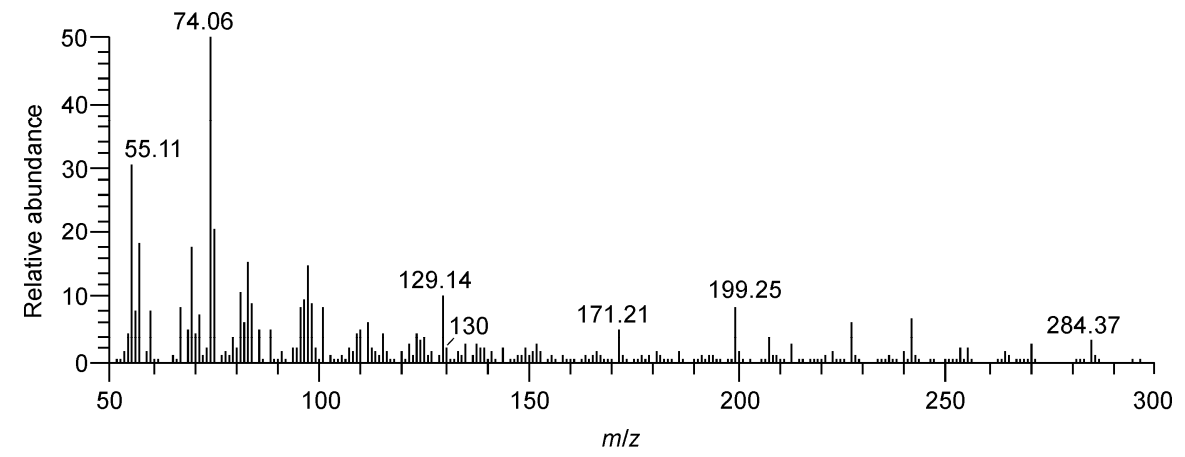

Figure 5 Mass spectra of 10me16:0 fatty acid.

Table 2 Organic geochemistry parameters for oils from Zhiluo Formation sandstones ${ }^{\text {a) }}$

\begin{tabular}{lcccccc}
\hline & ZKA75-12-2 & ZKA67-3-1 & ZKA32-8 & WT11-1 & 2-47-F [10] & 2-62-A [10] \\
\hline $\mathrm{Pr} / \mathrm{C}_{17}$ & 0.72 & 0.61 & 0.52 & 0.90 & 0.53 & 0.66 \\
$\mathrm{Ph} / \mathrm{C}_{18}$ & 0.90 & 0.81 & 0.50 & 0.94 & 0.57 & 0.68 \\
$\mathrm{Ts} / \mathrm{Tm}$ & 1.08 & 1.07 & 1.05 & 1.04 & 1.18 & 1.12 \\
$\mathrm{DTs} / \mathrm{DTm}$ & 0.92 & 1.22 & 0.91 & 0.16 & 1.03 & 1.22 \\
$29 \mathrm{DH} / 30 \mathrm{H}$ & 0.16 & 0.16 & 0.15 & 0.16 & 0.18 & 0.18 \\
$29 \mathrm{DH} / 29 \mathrm{H}$ & 0.30 & 0.33 & 0.30 & 0.32 & 0.26 & 0.29 \\
\hline
\end{tabular}

a) F, Fluid inclusion oils; A, absorbed oils. 

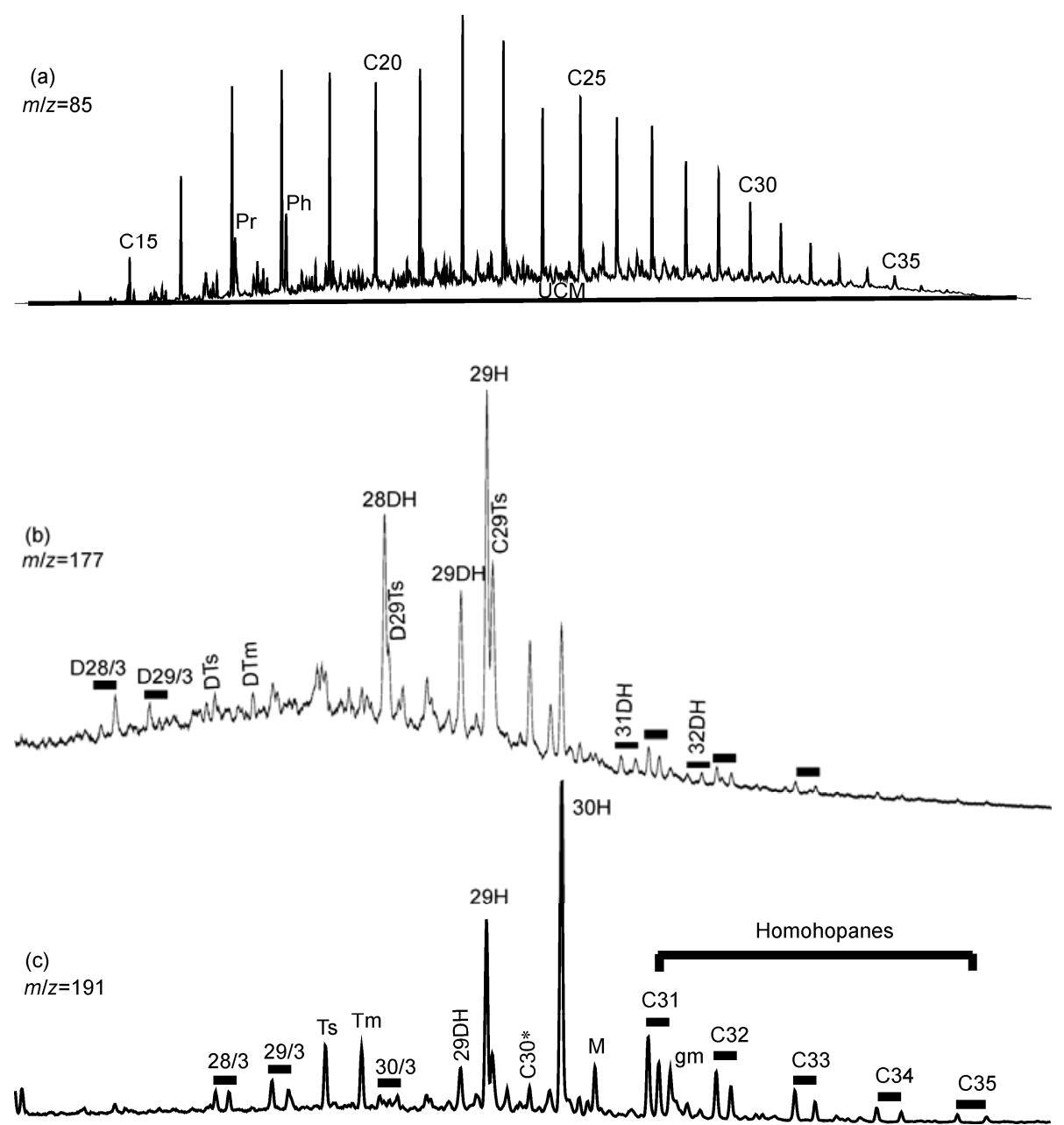

Figure 6 Partial $\mathrm{m} / \mathrm{z}=85,191$ and 177 mass chromatograms showing existence of unresolved complex mixtures (UCM) (a) and abundant demethylated hopanes and tricyclic terpanes (b), (c) in oil extracted from sandstone in well ZKA32-8. Compound identifications: H, 17 $\alpha, 21 \beta$ hopanes; M, $\mathrm{C}_{30} 17 \beta 21 \alpha$ moretane; D, 25-norhopanes; $\mathrm{C}_{30}{ }^{*}, \mathrm{C}_{30} 17 \alpha 21 \beta$ diahopane; 29Ts, $\mathrm{C}_{29}$ 18 $\alpha 21 \beta$-30-norhopane; gm: gammacerane; 28/3, $\mathrm{C}_{28}$ tricyclic terpane; $29 / 3, \mathrm{C}_{29}$ tricyclic

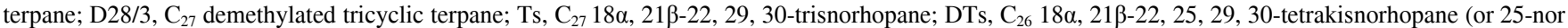
$\mathrm{Ts}) ; \mathrm{Tm}, \mathrm{C}_{27} 17 \alpha, 21 \beta-22,29,30$-trisnorhopane; DTm, 25-nor Tm; and so on.

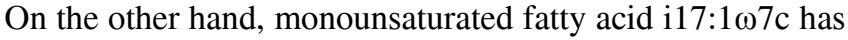
been shown to be a main component of Desulfovibrio [23] and is likely to be a characteristic biomarker used for identification of Desulfovibrio [36].

Except for sample WT11-2, another 4 samples contained iso- and anteiso-fatty acids, including i15:0, a15:0 and a17:0, with contents of 2.3 to $5.4 \%$ (Table 1). Significantly,

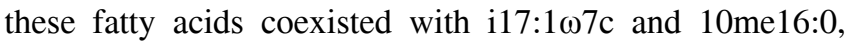
which are characteristic biomarkers of Desulfovibrio and Desulfobacter sp., respectively, and indicate the presence of sulfate-reducing bacteria.

Thus, based on fatty acid distributions, it can be concluded that sulfate-reducing bacteria (Desulfovibrio and Desulfobacter sp.) have been present in the deposit. This conclusion is consistent with previous research, based on morphological evidence and sulfur isotopic composition suggesting Desulfobacterium vacuolatum and Desulfovibrio piger were present during $U$ mineralization [10]. The result is also similar to modern SRB detected from the Hongshitan sandstone-type U deposit in Xinjiang, NW China [40]. Thus, fatty acid analyses, in this case, providing a good method to trace organisms in the deposit. In fact, the fatty acids analyzed in this study may be derived from modern and ancient microorganisms, including those during the period of $U$ mineralization. Thus, it is very likely that SRB survived and grew since the $\mathrm{U}$ mineralization interval of 9.8 to $22 \mathrm{Ma}$.

In this study, fatty acids, such as 16:0, 16:107c and $18: 1 \omega 7 \mathrm{c}$, were detected from all samples. In fact, SRB have been shown to contain these fatty acids. However, if they were derived from SRB, their contents are not expected to be higher than those biomarkers characteristic of SRB. Fatty

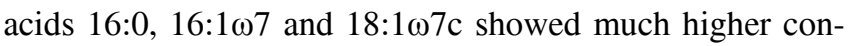
tents than $117: 1 \omega 7 \mathrm{c}$ and 10me16:0, suggesting that most of the former fatty acids were derived from other sources rather than SRB.

It is known that saturated or monounsaturated fatty acids, such as 16:0, 16:1 $1 \omega 7$ and $18: 1 \omega 7 \mathrm{c}$, can be derived from cyanobacteria or methanogens [20]. However, in the meth- 


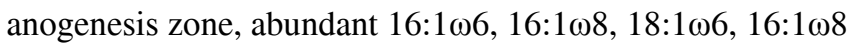
also are expected (Zhang et al., 2005 and references therein) [27]. Lacking of monounsaturated fatty acids in this study rules out the possibility of methanogens were a main source.

Jahnke et al. [41] separated cyanobacteria from stromatolites of Yellowstone National Park, USA, and found that $>70 \%$ polar fatty acid components of the cyanobacteria were composed of 16:0, 16:1, 18:0 and 18:1. No cyanobacteria could be expected to grow from freshwater braided rivers during the deposition of the sandstones in the area. However, hydrocarbons within the sandstones may have been derived from a lacustrine environment similar to the Yangchang Formation mudstone $[10,18,19]$. In this and previous studies, no $2 \alpha$ methyl hopanes, a characteristic biomarker of cyanobacteria [41-43], have been detected from the sandstones or the potential source rocks of the area $[10,18,19]$. This indicates that it is unlikely for $16: 0$, $16: 1 \omega 7 \mathrm{c}$ and $18: 1 \omega 7 \mathrm{c}$ detected in this study to have a cyanobacterial origin.

Fatty acids $16: 1 \omega 7 \mathrm{c}, 18: 1 \omega 7 \mathrm{c}$ and $16: 0$ accounted for $2.7 \%-8.7 \%, 20.7 \%-30.7 \%$ and $30 \%-44 \%$, respectively, of the total fatty acids in this study. They have been shown to indicate Beggiatoa, Thioploca and other sulfur-oxidizing bacteria in $\mathrm{H}_{2} \mathrm{~S}$-rich marine environments $[27,44,45]$. For example, Zhang et al. [27] identified Beggiatoa bacteria based on detection of $16: 1 \omega 7$ and $18: 1 \omega 7 \mathrm{c}$ from a microbial mat sample in gas hydrates and cold seeps from the Gulf of Mexico, and showed that fatty acids of the bacteria were composed of $16: 1 \omega 7 \mathrm{c}(53.6 \%), 16: 1 \omega 7 \mathrm{t}$ (12.8\%), 16:0 $(8.3 \%)$ and $18: 1 \omega 7 \mathrm{c}(16.6 \%)$. McCaffrey et al. [44] performed fatty acid analyses on two Thioploca species from the Peru upwelling region. In these species, 16:1 107 , $18: 1 \omega 7 \mathrm{c}$ and $16: 0$ accounted for 40.3 to $42.5 \%, 36.0$ to $37.8 \%$ and 17.3 to $18.0 \%$ of the total fatty acids, respectively. Jacq et al. [45] reported the lipid profiles of "Thiothrix-like" bacteria in a whitish mat from a subtidal hydrothermal vent area in southern California, and showed that fatty acids of these bacteria were dominated by 16:0,

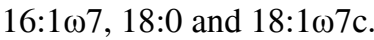

Thus, the detection of $16: 1 \omega 7,18: 1 \omega 7 \mathrm{c}$ and $16: 0$ fatty acids in the study suggest that sulfur-oxidizing bacteria, such as Beggiatoa and Thioploca, may have contributed significantly to the lipid pool. Much higher contents of $18: 1 \omega 7 \mathrm{c}$ compared to $16: 1 \omega 7$ indicate additional sources for $18: 1 \omega 7 \mathrm{c}$.

\subsection{Bacterial sulfate reduction and oxidation of petroleum hydrocarbons}

Results from this study, obtained from GC-MS analyses of oils from four sandstones, are similar to those reported by Cai et al. [10]. The oils show relatively high $\mathrm{Pr} / \mathrm{nC}_{17}, \mathrm{Ph} /$ $\mathrm{nC}_{18}, 29 \mathrm{DH} / 30 \mathrm{H}, 29 \mathrm{DH} / 29 \mathrm{H}$ ratios and contain demethylated tricyclic terpanes. GC-MS data $(m / z=85)$ show prominent humps of unresolved complex mixtures (UCM). 25-norhopanes in the oils are commonly generated by bacterial removal of the methyl at $\mathrm{C}-10$ from the regular hopanes. Thus, the presence of 25-norhopanes in the oils indicates that they have been heavily biodegraded by bacteria [46]. An increasing number of studies indicate that biodegradation in petroleum reservoirs was likely caused by anaerobic microorganisms rather than by aerobic microorganisms, although anoxic biodegradation occurs at a slower rate [47].

Biodegraded oils were found in fluid inclusions in ore-stage calcite. The calcite shows $\delta^{13} \mathrm{C}$ values mainly lighter than $-10 \%$, as low as $-27.6 \%$, and intimate intergrowth with ${ }^{32} \mathrm{~S}$-rich pyrite and coffinite [10]. Thus, hydrocarbons may have been involved in $U$ mineralization through biodegradation. SRB may have degraded the hydrocarbons directly, or utilized products of oxic biodegradation to produce ${ }^{12} \mathrm{C}$-rich $\mathrm{CO}_{2}$ and thus precipitate as calcite. These processes occurred simultaneously with the reduction of sulfate to $\mathrm{H}_{2} \mathrm{~S}$ and $\mathrm{U}(\mathrm{VI})$ to $\mathrm{U}(\mathrm{IV})$. Since there is no evidence to rule out the possibility of oxic biodegradation prior to sulfate reduction, it is possible for the hydrocarbons to have been degraded by oxic bacteria. However, since it is very likely that not enough oxygen was present for oxic bacteria to grow, sulfate-reducing bacteria alone, or combined with other anaerobic bacteria, may have degraded hydrocarbons in the sandstones.

\subsection{Multi-step bacterial sulfate reduction and sulfide oxidization}

The $\delta^{34} \mathrm{~S}$ values of ore-stage pyrite in the Dongsheng deposit were variable and as low as $-39.2 \%$ [10]. Although the source of the sulfate is not clear, Phanerozoic seawater has $\delta^{34} \mathrm{~S}$ values not lighter than $11 \%$ [ [48]. Thus, the differences in $\delta^{34} \mathrm{~S}$ values between the sulfate and the lightest pyrite were greater than $50 \%$ o. On the other hand, based on pure culture experiments, the maximum achievable fractionation during single-step BSR is $46 \%$ [49]. This suggests that there existed multi-step bacterial sulfate reduction and re-oxidization. That is, bacterial sulfate reduction to sulfide-re-oxidization of the sulfide to sulfate-reduction of the sulfate to sulfide took place in Dongsheng uranium deposit. The results are consistent with the detection of abundant SOB fatty acids.

\section{Conclusions}

(1) Fatty acids of the Dongsheng uranium deposit consist mainly of $\mathrm{C}_{15}-\mathrm{C}_{18}$ compounds, which contain branched saturated fatty acids (i.e. i15:0, a15:0 and a17:0) and monoun-

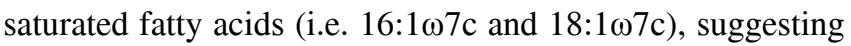
an origin of bacteria in the deposit.

(2) Fatty acid, such as i15:0, a15:0 and a17:0 coexisted with $117: 1 \omega 7 \mathrm{c}$ and $10 \mathrm{me} 16: 0$, and support the presence of 
Desulfovibrio and Desulfobacter sp. and other sulfatereducing bacteria. The presence of sulfur-oxidizing bacteria (SOB), such as Beggiatoa and Thioploca, is indicated by the presence of $16: 1 \omega 7$ and $18: 1 \omega 7 \mathrm{c}$ fatty acids.

(3) The presence of abundant SOB fatty acids and sulfur isotope fractionations greater than $50 \%$ indicate that there existed multi-step bacterial sulfate reduction. That is, bacterial sulfate reduction to sulfide-re-oxidization of the sulfide to sulfate-reduction of the sulfate to sulfide occurred in the Dongsheng uranium deposit.

We appreciate constructive comments provided by the reviewers, which improved the manuscript. Dr Guan Hongxiang and PhD candidate Jiang Aizhu (Both from GIGCAS) provided guidance on analyses of the samples. This work was supported by the Knowledge Innovation Program of the Chinese Academy of Sciences (KZCX2-YW-JC102), and National Basic Research Program of China (2011CB808800).

1 Jensen M L. Sulfur isotopes and the origin of sandstone-type uranium ore deposits. Econ Geol, 1958, 53: 598-616

2 Rackey R I. Environment of Wyoming Tertiary uranium deposits. AAPG Bull, 1972, 56: 755-774

3 Reynolds R L, Goldhaber M B. Biogenic and nonbiogenic oreforming processes in the South Texas uranium district evidence from the Panna Maria deposit. Econ Geol, 1982, 77: 541-556

4 Goldhaber M B, Hemingway B S, Mohagheghi A, et al. Origin of coffinite in sedimentary rocks by a sequential adsorption-reduction mechanism. Bull Mineral, 1987, 110: 131-144

5 Milodowski A E, West J M, Pearce J M, et al. Uranium-mineralized microorganisms associated with uraniferous hydrocarbons in southwest Scotland. Nature, 1990, 347: 465-467

6 Landais P. Bitumens in uranium deposits. In: Parnell J, Kucha H, Landais P, eds. Bitumens in Ore Deposits. Berlin: Springer-Verlag, 1993. 213-238

7 Morrison S J, Parry W T. Age and formation conditions of alteration associated with a collapse structure, Temple Mountain uranium district, Utah. Geol Soc Amer Bull, 1998, 100: 1069-1077

8 Zhang R L, Ding W L. Discussion on geological characteristics of Nuheting type uranium deposit and the relation between oil and gasbearing water and uranium metallogenesis (in Chinese). Uran Dep Geol, 1994, 10: 257-271

9 Curiale J A, Bloch S, Rafalska-Bloch J, et al. Petroleum-related origin for uraniferous organic-rich nodules of southwestern Oklahoma. AAPG Bull, 1983, 67: 588-608

10 Cai C F, Dong H L, Li H T, et al. Mineralogical and geochemical evidence for coupled bacterial uranium mineralization and hydrocarbon oxidation in the Shashagetai deposit, NW China. Chem Geol, 2007, 236: 167-179

11 Cai C F, Li H T, Qin M K, et al. Biogenic and petroleum-related oreforming processes in Dongsheng uranium deposit, NW China. Ore Geol Rev, 2007, 32: 262-274

12 Lovley D R, Philips E J P. Reduction of uranium by Desulfovibro desulfuricans. Appl Environ Microb, 1992, 58: 850-856

13 Lovley D R, Roden E E, Phillips E J P, et al. Enzymatic iron and uranium reduction by sulfate-reducing bacteria. Mar Geol, 1993, 113: 41-53

14 Abdelouas A, Lu Y, Lutze W, et al. Reduction of U(VI) to U(IV) by indigenous bacteria in contaminated ground water. J Contam Hydrol, 1998, 35: 217-233

15 Min M Z, Xu M H, Chen J, et al. Evidence of uranium biomineralization in sandstone-hosted roll-front uranium deposits, northwestern China. Ore Geol Rev, 2005, 26: 198-206

16 Cuney M. Evolution of uranium fractionation processes through time: Driving the secular of uranium deposit types. Econ Geol, 2010, 105:
553-569

17 Tuo J C, Zhang M F, Wang X B. The content and significance of fatty acid methyl esters in Dongsheng sedimentary uranium ore deposits, Ordos basin, China (in Chinese). Acta Sediment Sin, 2006, 24: 432-439

18 Li H T, Cai C F, Luo X R, et al. Geochemical characteristics and source of hydrocarbon inclusions in Zhiluo Formation sandstone in Dongsheng area, northern Ordos basin (in Chinese). Acta Sediment Sin, 2007, 25: 564-570

19 Tuo J C, Chen R, Zhang M F, et al. Occurrences and distributions of branched alkylbenzenes in the Dongsheng sedimentary uranium ore deposits, China. J Asian Earth Sci, 2010, 39: 770-785

20 Duan Y, Luo B J, Qian J S, et al. Study on organic geochemistry of fatty acids in recent sediments from Nansha Sea area (in Chinese). Mar Geol Quat Geol, 1996, 16: 23-31

21 Zhang Y D, Sun Y G, Xie L J, et al. The occurrence and significance of $\mathrm{C} 25 \mathrm{HBI}$ in Cenozoic saline lacustrine source rocks from the Western Qaidam Basin, NW China. Chin Sci Bull, 2011, 56: 13901398

22 Nichols P D, Guckerta J B, White D C. Determination of monosaturated fatty acid double-bond position and geometry for microbial monocultures and complex consortia by capillary GC-MS of their dimethyl disulphide adducts. J Microb Meth, 1986, 5: 49-55

23 Elvert M, Boetius A, Knittel K. Characterization of specific membrane fatty acids as chemotaxonomic markers for sulfate-reducing bacteria involved in anaerobic oxidation of methane. Geomicrobiol J, 2003, 20: 403-419

24 Ringelberg D B, Davis J D, Smith G A, et al. Validation of signature polar lipid fatty acid biomarkers for alkane-utilizing bacteria in soils and subsurface aquifer materials. FEMS Microbiol Ecol, 1989, 62: $39-50$

25 Guan H X, Feng D, Wu N Y, et al. Fatty-acids and their $\delta^{13} \mathrm{C}$ characteristics of seep carbonates from the northern continental slope of Gulf of Mexico. Chin Sci Bull, 2010, 55: 730-735

26 Zhang C L, Li Y, Wall J D, et al. Lipid and carbon isotopic evidence of methane-oxidizing and sulfate-reducing bacteria in association with gas hydrates from the Gulf of Mexico. Geology, 2002, 30: 239242

27 Zhang C L, Huang Z Y, Cantu J, et al. Lipid biomarkers and carbon isotope signatures of a microbial (Beggiatoa) mat associated with gas hydrates in the Gulf of Mexico. Appl Environ Microb, 2005, 71: 2106-2112

28 Apon J M B, Nicolaidesn N. The determination of position isomers of the methyl branched fatty acid methyl esters by capillary GCMS. J Chromatogr Sci, 1975, 13: 467-473

29 Huang Y, Metzger P, Eglinton G, et al. Glacial-interglacial environmental changes inferred from molecular and compound-specific delta ${ }^{13} \mathrm{C}$ analyses of sediments from Sacred Lake, Mt. Kenya. Geochim Cosmochim Acta, 1999, 63: 1383-1404

30 Kaneda T. Iso- and anteiso-fatty acids in bacteria: Biosynthesis, function, and taxonomic significance. Microbiol Mol Biol Rev, 1991, 55: 288-302

31 Erwin J A. Comparative biochemistry of fatty acids in eukaryotic microorganisms. In: Lipids and Biomembranes of Eukaryotic Microorganisms. New York: Academic Press, 1973. 91-143

32 Perry G J, Volkman J K, Johns R B. Fatty acids of bacterial prigin in contemporary marine sediments. Geochim Cosmochim Acta, 1979, 43: $1715-1725$

33 Taylor J, Parkes R J. The cellular fatty acids of the sulphatereducing bacteria, Desulfobacter sp., Desulfobulbus sp., and Desulfovibrio desulfuricans. J Gen Microbiol, 1983, 129: 3303-3309

34 Vainshtein M, Hippe H, Kroppenstedt R M. Cellular fatty acid composition of Desulfovibrio species and its use in classification of sulfate reducing bacteria. Syst Appl Microbiol, 1992, 15: 554-566

35 Londry K L, Jahnke L L, Des Marais D J. Stable carbon isotope ratios of lipid biomarkers of sulfate-reducing bacteria. Appl Environ Microb, 2004, 70: 745-751

36 Edlund A, Nichols P D, Roffey R, et al. Extractable and lipopolysaccharide fatty acid and hydroxy fatty acid profiles from Desulfovibrio 
species. J Lipid Res, 1985, 26: 982-988

37 Lechevalier M P. Lipids in bacterial taxonomy-A taxonomists' view. Crit Rev Microbiol, 1977, 5: 109-210

38 Kaneshino T, Thomas P J. Methylation of fatty acids in a methioninedependent Agrobacterium tumefaciens controlled with exogenous methionine. BBA Mol Cell Biol L, 1969, 187: 26-35

39 Dowling N J E, Widdel F, White D C, et al. Phospholipid ester-linked fatty acid biomarkers of acetate-oxidizing sulphate-reducers and other sulphide-forming bacteria. J Gen Microbiol, 1986, 132: 1815-1825

40 Huang J X, Gen H B, Qiao H M, et al. Microbe in the Shihongtan Uranium Deposit and their metallogenic significance (in Chinese). Acta Sediment Sin, 2006, 24: 394-398

41 Jahnke L L, Embaye T, Hpoe J, et al. Lipid biomarker and carbon isotopic signatures for stromatolite-forming, microbial mat communities and Phormidium cultures from Yellowstone National Park. Geobiology, 2004, 2: 31-47

42 Xie S C, Pancost R D, Yin H F, et al. Two episodes of microbial change coupled with Permo/Triassic faunal mass extinction. Nature, 2005, 434: 494-497

43 Summons R E, Jahnke L L, Hope J M, et al. 2-Methylhopanoids as biomarkers for cyanobacterial oxygenic photosynthesis. Nature, 1999, 400: 554-557

44 McCaffrey M A, Farrington J W, Repeta D J. Geochemical implication of the lipid composition of Thioploca spp. from the Peru upwelling region- $15^{\circ} \mathrm{S}$. Org Geochem, 1989, 14: 61-68

45 Jacq E, Prieur D, Nichols P, et al. Microscopic examination and fatty acid characterization of filamentous bacteria colonizing substrate around subtidal hydrothermal vents. Arch Microbiol, 1989, 152: 64-71

46 Peters K E, Moldowan J M. The Biomarker Guide. Interpreting Molecular Fossils in Petroleum and Ancient Sediments. New Jersey: Prentice Hall, 1993

47 Larter S, Wilhelms A, Head I. The controls on the composition of biodegraded oils in the deep subsurface-part 1: Bio-degradation rates in petroleum reservoirs. Org Geochem, 2003, 34: 601-613

48 Claypool G E, Holser W T, Kaplan I R, et al. The age curves of sulfur and oxygen isotopes in marine sulfate and their mutual interpretation. Chem Geol, 1980, 28: 199-260

49 Kaplan I R, Rittenberg S C. Microbiological fractionation of sulfur isotopes. J Gen Microbiol, 1964, 34: 195-212

Open Access This article is distributed under the terms of the Creative Commons Attribution License which permits any use, distribution, and reproduction in any medium, provided the original author(s) and source are credited. 